\title{
Granitic and magmatic bodies in the deep crust of the Son Narmada Region, Central India: constraints from seismic, gravity and magnetotelluric methods
}

\author{
K. Naganjaneyulu \\ National Geophysical Research Institute (NGRI), Council of Scientific and Industrial Research, Hyderabad 500 007, India \\ (Received October 14, 2009; Revised August 13, 2010; Accepted October 29, 2010; Online published January 26, 2011)
}

\begin{abstract}
Magnetotelluric (MT) data at 24 locations in the Son Narmada region, Central India, were collected across the Tapti North Fault and Son Narmada Fault along the Chinchpada-Godhra profile $(220 \mathrm{~km})$. MT impedance tensors were then estimated in the period range $0.001-1,000 \mathrm{~s}$ using robust processing codes. The $\mathrm{N} 70^{\circ} \mathrm{E}$ geo-electric strike direction was obtained by multi-site, multi-frequency analysis. The data were modeled using non-linear conjugate gradient scheme taking both apparent resistivity and phase into account. The two-dimensional MT model obtained (after static shift correction) represents resistive bodies $(1,000-3,000 \mathrm{ohm}-\mathrm{m})$ and conductive bodies $(<20 \mathrm{ohm}-\mathrm{m})$ in the deep crust. The resistive bodies in the lower crust are interpreted to be granitic intrusive complexes. The conductor on the south of Son Narmada Fault is attributed to the presence of magmatic bodies due to underplating, and the conductor on the north as due to the presence of fluids. The highly resistive $(>2,000 \mathrm{ohm}-\mathrm{m})$ upper crust is interpreted to comprise felsic rocks of granitic composition, and the low-resistive $(<100 \mathrm{ohm}-\mathrm{m})$ deep crust as being composed of dense mafic granulites. The Domal upwarp structure near Son Narmada Fault, with a thick felsic crust sandwiched between the mafic and intermediate crust, can be explained by underplated sediments/felsic crust which jacked-up the lithounits above.
\end{abstract}

Key words: Son Narmada region, electrical resistivity, gravity, seismic velocity, underplating, fluids, magnetotellurics.

\section{Introduction}

The Son Narmada region is a complex and broad tectonic region located between latitudes $20^{\circ}$ and $24^{\circ} \mathrm{N}$ and longitudes $73^{\circ}$ and $82^{\circ} \mathrm{E}$ in Central India. The major part of the Son Narmada region is covered by basalts and is known to be a large igneous province. Several gravity, seismic, and magnetotelluric studies have been carried out in the region to gain an understanding of the tectonic processes operating across the area. These studies have focused on the area east of Barwani (Fig. 1(a)) with the aim of delineating the deep crustal structure. To date, the western part of the Son Narmada region is relatively unexplored (Fig. 1(a)).

Early gravity studies in the region provided Bouguer anomaly maps (Fig. 1(b)) and inferred block structures (Verma and Banerjee, 1992). These were followed by gravity studies (e.g., Singh and Meissner, 1995) that identified underplated material with a thickness varying from 5 to $20 \mathrm{~km}$. More recently, seismic and gravity studies have estimated the crustal thickness is about $40 \mathrm{~km}$ (Tewari and Kumar, 2003) (Fig. 2) while early studies interpreted Moho reaching faults (Kaila et al., 1985). Based on the results of magnetotelluric studies, Patro et al. (2005) inferred the presence of fluids in the deep crust. The temperature at Moho depth is estimated to be $500^{\circ}-580^{\circ} \mathrm{C}$ (Rai

Copyright (c) The Society of Geomagnetism and Earth, Planetary and Space Sciences (SGEPSS); The Seismological Society of Japan; The Volcanological Society of Japan; The Geodetic Society of Japan; The Japanese Society for Planetary Sciences; TERRAPUB.

doi:10.5047/eps.2010.10.006 and Thiagarajan, 2006), indicating a cold lithosphere beneath the zone. The surface heat flow values are normally $>50 \mathrm{~mW} / \mathrm{m}^{2}$ (Ravi Shankar, 1988).

In the eastern and central part of the Son Narmada region, the processes of uplift and erosion of upper crustal layers have been inferred from seismic (Kaila et al., 1989; Tewari and Kumar, 2003) and magnetotelluric studies (Gokarn et al., 2001). In contrast, the more westerly region (west of Barwani; Fig. 1(a)) has been interpreted as a graben structure (Tewari and Kumar, 2003).

In the study reported here, I provide the first detailed description of the deep crustal geo-electric structure for this unexplored region from Chinchpada to Godhra using the magnetotelluric (MT) method. The MT method is considered to be one of the best methods for imaging models that envisage the presence of fluids, underplated material, and melt at the deep crustal depths (for a review, see Jones, 1992). Consequently, the use of MT in delineating deep crustal structures, as discussed here is a wellaccepted and popular method that is applied world-wide. For example, MT studies (Wannamaker and Doerner, 2002) conducted in the Ruby mountains imaged resistive structures close to deep crustal, steeply dipping fault zones. It has been inferred that the zones acts as conduits for upper crustal-induced electric current flow and, therefore, that the lower crust is heterogeneous. It has also been inferred that the crustal breaks would decrease the effective elastic thickness and represent the deep crustal fault zones in which major earthquakes nucleate (Wannamaker 
a)

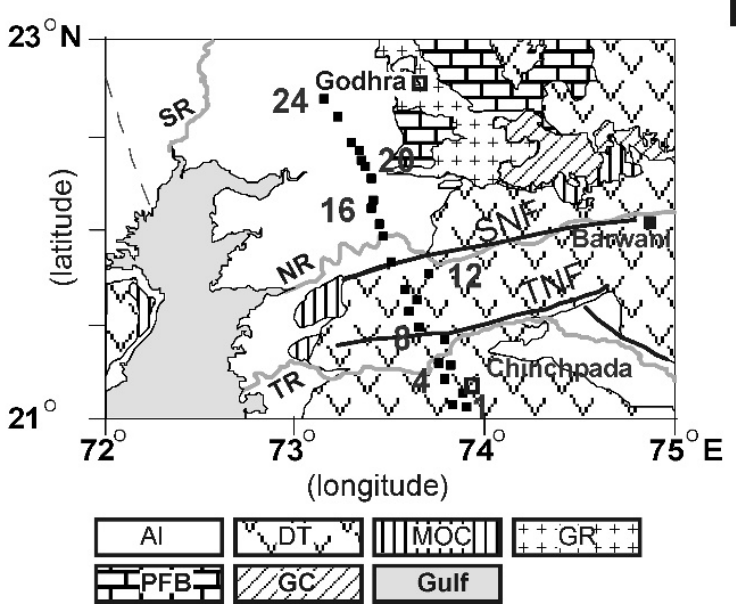

b)

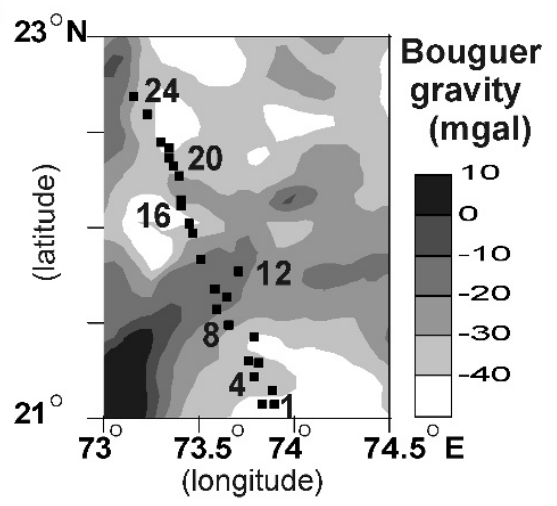

Fig. 1. (a) MT stations are plotted over the geological map of the study region. Rock types: Al-Alluvium, DT-Deccan Traps (Basalts), MOC_-Marginal Overlap Cover, GR_-Granites, PFB_-Proterozoic Fold Belt; GC_-Gneissic Complex and also Gulf (of Cambay) are shown. Major faults in the region are: TNF, Tapti North Fault; SNF, Son Narmada Fault. Major rivers are: TR, Tapti river; NR, Narmada river; SR, Sabarmati river. (b) Bouguer anomaly map of the study region.

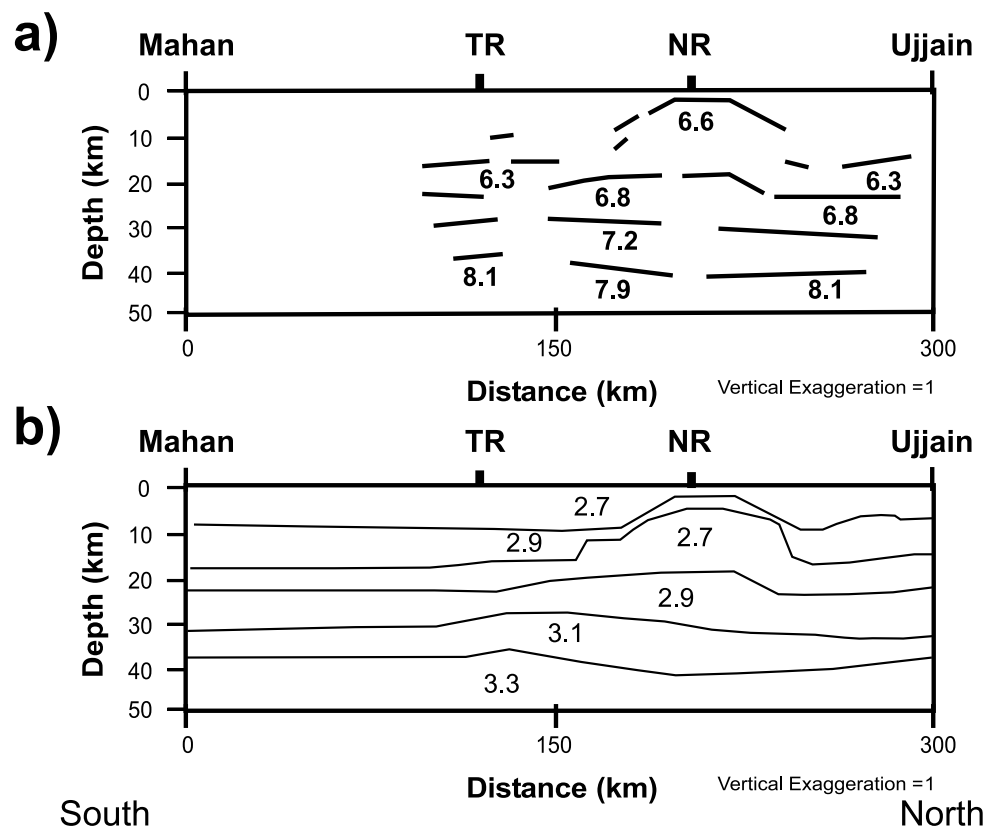

Fig. 2. (a) Simplified velocity (km/s) cross-section along the Mahan-Ujjain profile (modified after Tewari and Kumar, 2003). (b) Simplified density $(\mathrm{gm} / \mathrm{cc})$ cross-section along the Mahan-Ujjain profile (modified after Tewari and Kumar, 2003). Rivers: TR, Tapti river; NR, Narmada river.

and Doerner, 2002). Some of the more recent studies have linked high-conducting anomalies in the deep crust with the presence of graphite and resistive anomalies in the uppermiddle crust and with igneous complexes of variable age (Almeida et al., 2005). MT studies (Bologna et al., 2005) from the Alto Paranaiba igneous province identified silicic dry rocks in the lower crust $(20-40 \mathrm{~km})$ based on high resistivities (1,000-10,000 ohm-m).

The objective of the study reported here was to image the electrical properties of the upper crustal and the lower crustal features in the Son Narmada region in order to identify the diverse processes of underplating, fluidrich regimes, and zones of partial melt, if any, along the Chinchpada-Godhra profile. These results have been integrated with results from other studies and inferences on rock types drawn.

\section{Magnetotelluric Data and Methodology}

Data along the Chinchpada-Godhra profile were collected at 24 stations with wide-band digital MT systems in single-site mode in the period range of 0.001-1,000 s. This 220-km-long profile, which traverses through the Tapti North Fault (TNF) and Son Narmada Fault (SNF), provides an opportunity to delineate the deep-crustal electrical resistivity structure over the region of the Alluvium and Deccan Trap (also known as Deccan Basalts) (Fig. 1(a)). The timeseries data were processed to obtain both the impedance tensors and induction vectors using a robust processing code (Ellinghaus, 1997). Because the induction vector data were not of high quality, impedance data in the period range 
a)

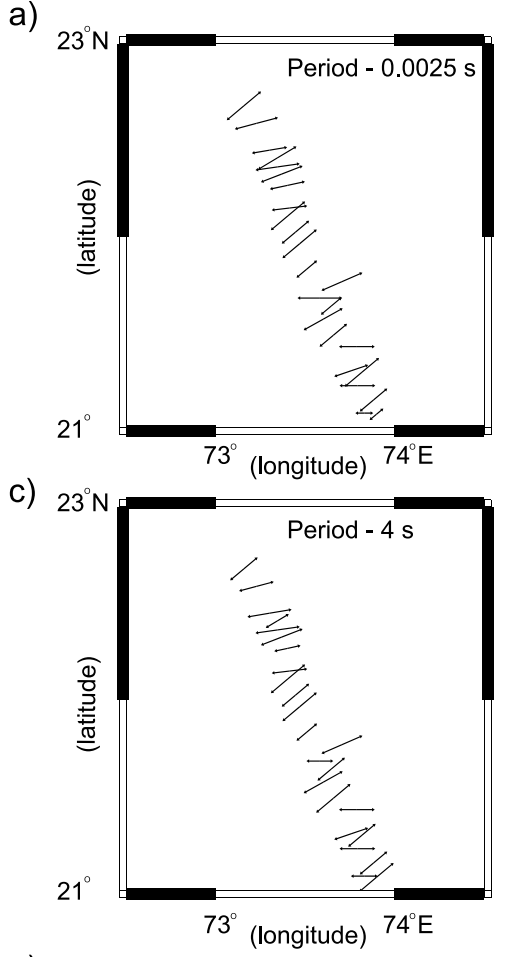

e)

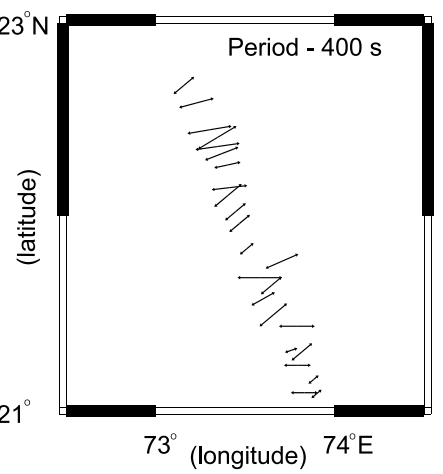

b)

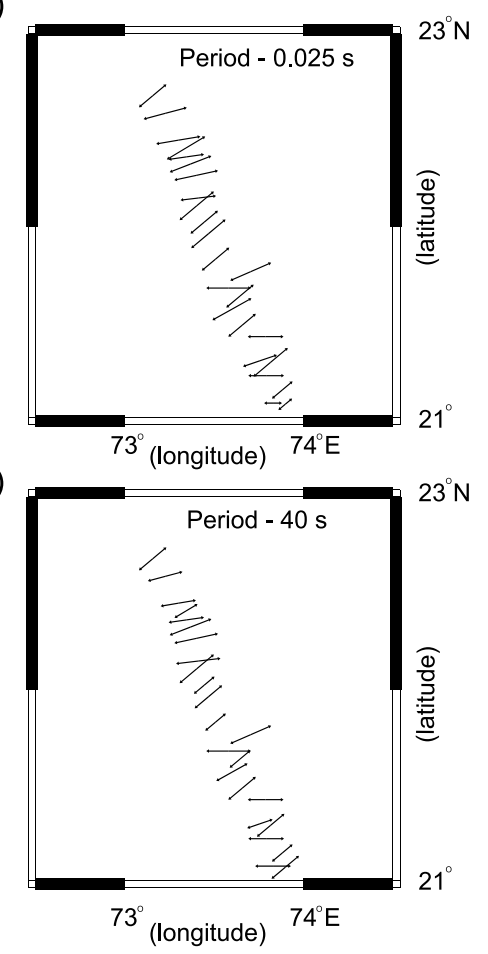

Strike error

$\longrightarrow \quad 0-1$

- $2-3$

$-\quad 3-4$

$-\quad 4-5$

$->5$

Fig. 3. Strike direction and misfit for periods $0.0025 \mathrm{~s}, 0.025 \mathrm{~s}, 4 \mathrm{~s}, 40 \mathrm{~s}$, and $400 \mathrm{~s}$.

0.01-1, $000 \mathrm{~s}$ were used in the modeling.

The multi-site, multi-frequency MT tensor decomposition code (McNeice and Jones, 2001) was used to estimate the geo-electric strike direction. Results for five representative periods are shown in Fig. 3. This analysis indicated a strike direction of approximately $\mathrm{N} 70^{\circ} \mathrm{E}$ for individual stations in the period range $0.001-1,000 \mathrm{~s}$ with low chi-square errors. This strike direction is coincident with the major strike direction of tectonic features in the Son Narmada region, and it is close to the strike direction reported in other MT studies in Central India, such as the study of Patro et al. (2005), who obtained $\mathrm{N} 75^{\circ} \mathrm{E}$ as the strike direction. Hence, the data were rotated to $70^{\circ}$. The data were not corrected for static shift effects and carried a two-dimensional (2-D) inversion using the non-linear conjugate gradient 2-D inversion algorithm of Rodi and Mackie (2001) with both strikeparallel-TE- and strike-perpendicular-TM-modes. The mesh sizes used were 102 horizontal and 185 vertical elements. The initial model was a homogeneous half-space model of $100 \mathrm{ohm}-\mathrm{m}$. More importance was given to phase data over apparent resistivity data and to TM data over TE data. For the TM and TE modes, the apparent resistivity error floors are 10 and $20 \%$ and the phase error floors 5 and $10 \%$, respectively, to obtain the initial model. This model was used to carry out the static shift correction. These data ( $70^{\circ}$ rotated and static shift corrected) are shown in the form of apparent resistivity and phase versus period as pseudosection and curves (Fig. 4(a) and (b)). These static shiftcorrected data were then again subjected to 2-D inversion for another 40 iterations. The root mean square error for the final model is 2.63 . The sensitivity analysis was carried out for this model based on the approach suggested in Rodi and Mackie (2001). In this method, the data are expressed as a logarithm of the complex apparent resistivity, and the model is expressed as a logarithm of resistivity. The sensitivity is the change in the logarithm of complex apparent resistivity (in the data) to a change in logarithm of resistivity (in the model). This sensitivity matrix is a real matrix with one row for the real part of a data set and the next row for the imaginary part of the data set. The output of the sensitivity values is the sum of the squares of each column and represent the sum over all the data (stations and frequencies) (Rodi and Mackie, 2001). In this study, the structures with sensitivity matrix values $>0.0001$ were con- 


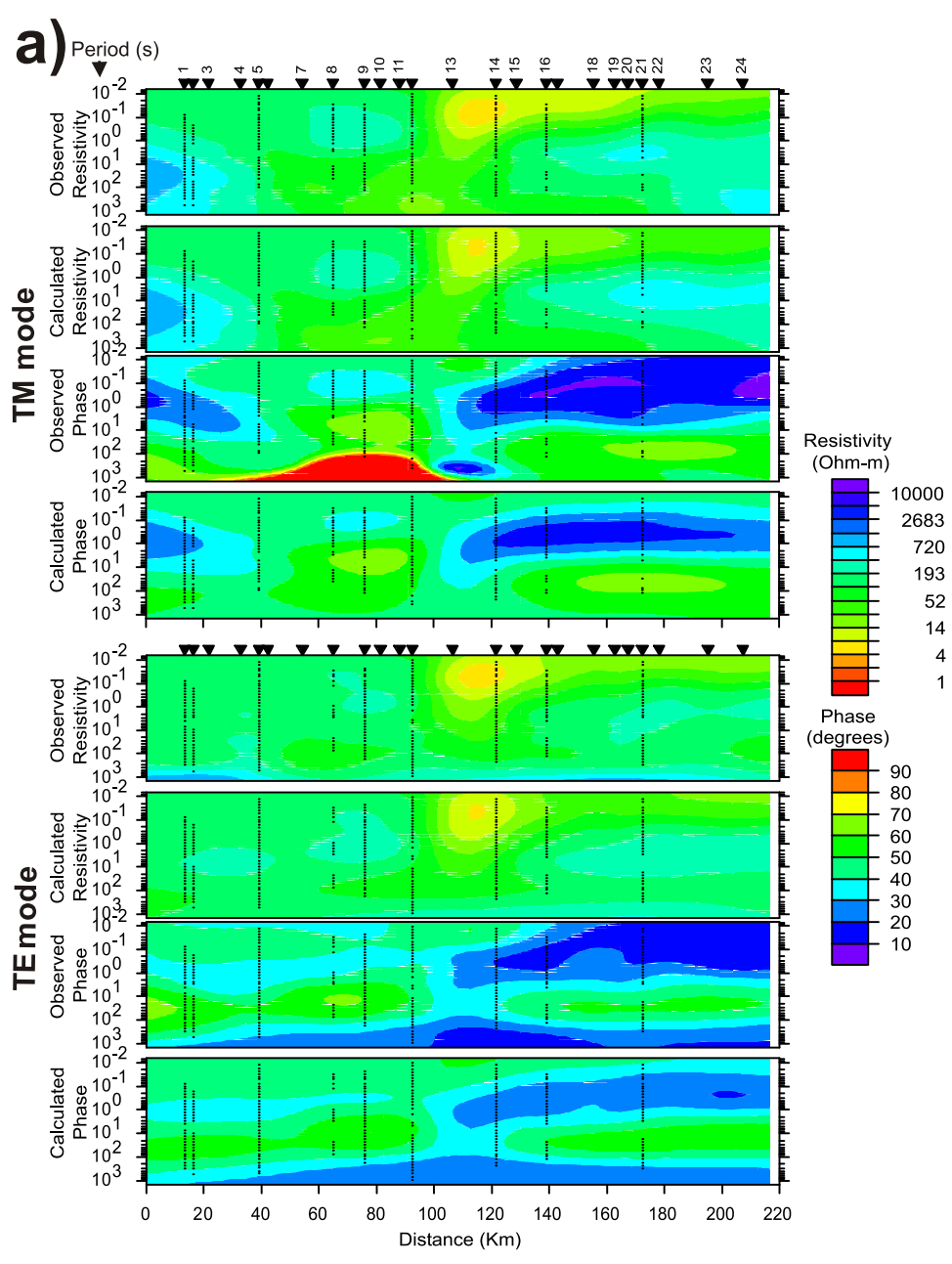

b)
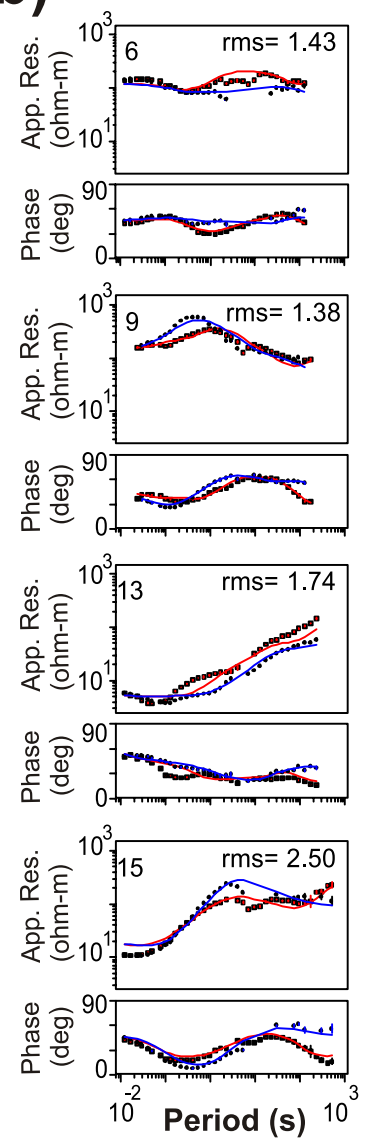

...TE Original ...TM Original

— TE Calculated — TM Calculated

\section{c)}

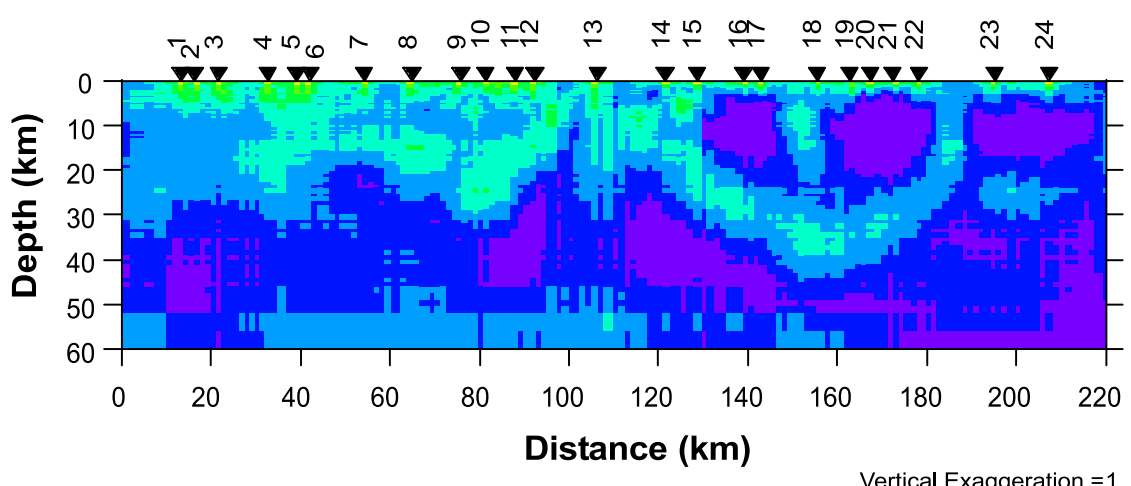

Sensitivity

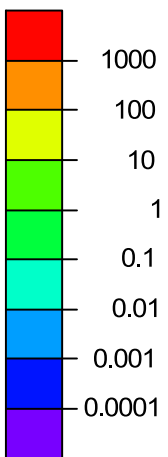

Fig. 4. (a) Apparent resistivity and phase data in the form of pseudo-sections for both the TM and TE modes along with the model (shown in Fig. 5(a)) response (b) Apparent resistivity, phase data, and model responses for a few stations. RMS errors are also shown. (c) Plot of sensitivity values for the model.

sidered to be resolved features, which is in agreement with other recent works, such as those by Brasse et al. (2002) and Ledo et al. (2004). Most of the Chinchpada-Godhra profile shows (Fig. 4(c)) sensitivity matrix values $>0.0001$ on the southern side of the profile. High-resistivity structures on the northern side show less sensitivity values. Since these are, in fact, resistive zones, less sensitivity values can be expected. The major feature visible in the model (Fig. 5(a)) is a high-resistive (2,000-10,000 ohm-m) upper crust along the profile that as a general rule varies in thickness from 12 to $20 \mathrm{~km}$, except near station 13 . The middle-lower crust is distinctly different, with resistive bodies ' $\mathrm{R} 1$ ' (below stations 4-8) and 'R2' (below station 13) and conductive bodies ' $\mathrm{C} 1$ ' (below stations 9, 10) and ' $\mathrm{C} 2$ ' (below station 18). The upper mantle resistivity is more than $500 \mathrm{ohm}-\mathrm{m}$, but needs to be determined with longer period data.

\section{Summary and Conclusions}

Several geophysical studies have been carried out in the complex Son Narmada region. The results of the MT mod- 


\section{a)}
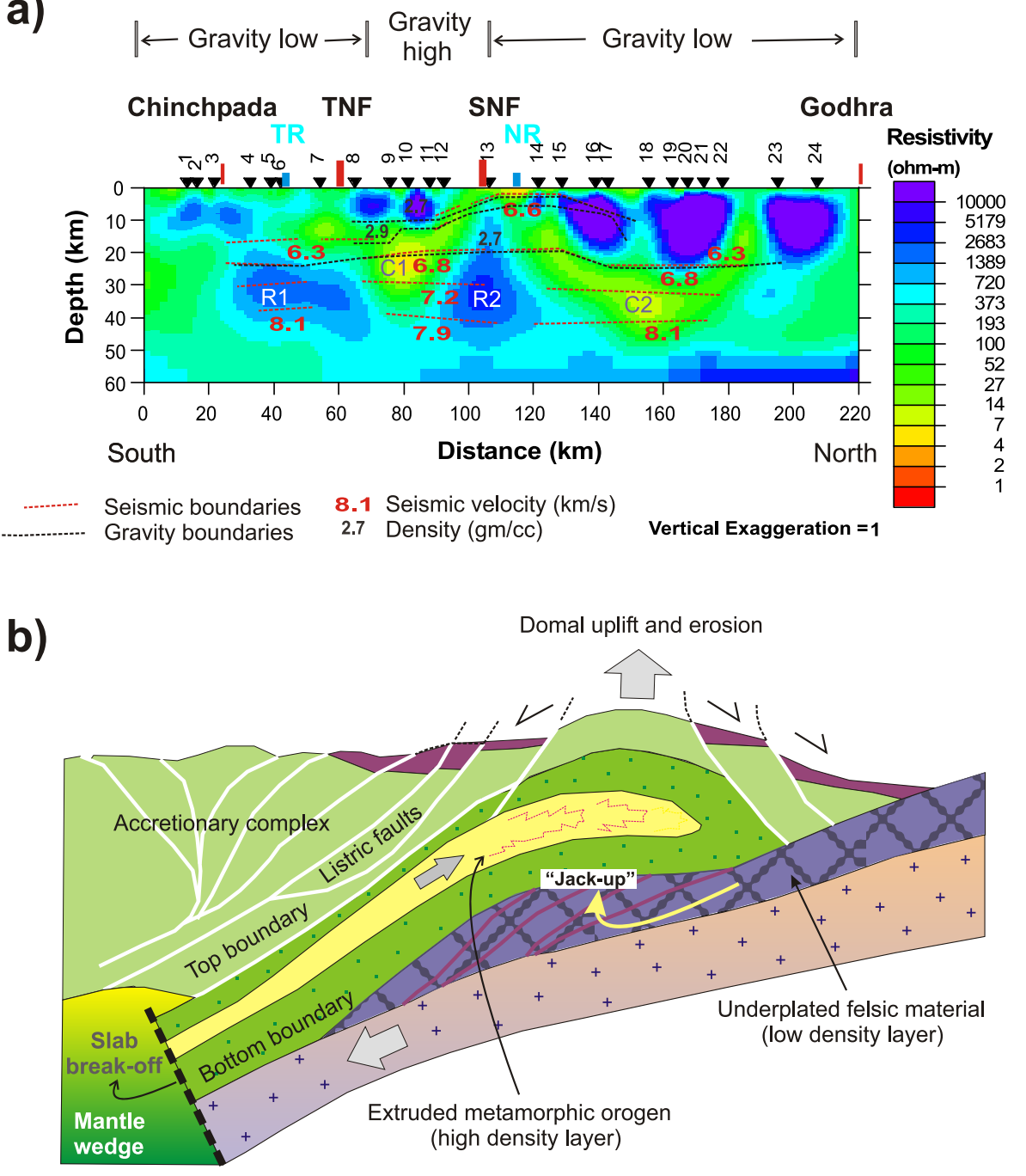

Fig. 5. (a) Deep geo-electric structure obtained from the 2-D MT model along the profile using the NLCG scheme. The seismic and gravity models (shown in Fig. 2) are superposed over the MT model. (b) A schematic section which explains the domal nature of the seismic patterns, which are high-density layers sandwiched between two low-density layers. In the MT model (shown in a), probable erosion of the high-resistive upper crust exposes the conducting mid-lower crust. This domal structure may have resulted through 'jack-up' by the underplated sediments during a complex tectonic process, such as subduction and exhumation of the orogenic core. See text for more details.

eling study reported here have been integrated with gravity, seismic, and regional heat flow studies to explain the deep crustal properties. The Bouguer gravity anomaly of the region shows a high gravity (approx. $-10 \mathrm{mgal}$ ) between stations 9 and 13. Other regions show gravity lows ranging from -20 to -50 mgal. Several similarities between the results obtained using this MT model and those from earlier gravity, seismic (Tewari and Kumar, 2003), and MT models (Gokarn et al., 2001) are discussed in the following section.

Along the Mahan-Ujjain profile $(200 \mathrm{~km}$ further east of the present profile), domal structures with a velocity $(6.6 \mathrm{~km} / \mathrm{s})$ in the upper crust near Narmada river are present (Figs. 2(a) and 5(a)). The crustal velocities here are generally $\leq 7.2 \mathrm{~km} / \mathrm{s}$ for the crust. The gravity model along the Mahan-Ujjain profile also shows a 10 - to $15-\mathrm{km}$-thick low-density $(2.7 \mathrm{gm} / \mathrm{cc})$ layer trapped between high-density (2.9 gm/cc) layers. Based on these models, Tewari and Kumar (2003) inferred the presence of mafic intrusives in this region. Using earlier MT models on the eastern part of Narmada Son region, Gokarn et al. (2001) reported a rel- atively low resistivity of $200 \mathrm{ohm}-\mathrm{m}$ and $6.5 \mathrm{~km} / \mathrm{s}$ in the upper crust. A similar low-resistive upper crustal structure near the Narmada river was also observed in the present study. Similarly, the MT model used here and earlier MT model reported by Gokarn et al. (2001) both found deep crustal conductors $(\mathrm{C} 1$ and $\mathrm{C} 2$ in Fig. 5(a)).

A general density $(2.70 \mathrm{gm} / \mathrm{cc})$, velocity $(6.0 \mathrm{~km} / \mathrm{s})$, and high resistivity $(2,000-10,000 \mathrm{ohm}-\mathrm{m})$ of the upper crustal rocks are to be inferred as granites, extending to about $12 \mathrm{~km}$ south of the Narmada river and up to about $22 \mathrm{~km}$ to the north. Earlier studies by Verma and Banerjee (1992) also share such an inference.

The results reveal that the region below the Tapti river shows anomalous high resistivity (1,000-3,000 ohm-m) in the deep crustal depths of $20-40 \mathrm{~km}$ (R1 in Fig. 5(a)). The region near SNF also shows anomalous high resistivity in the deep crust from 10 to $30 \mathrm{~km}$ (R2). This is an unexpected result since one would expect a conductor in MT models near a vertical Moho penetrating fault (Kaila et al., 1985). However, a gradual increase of apparent resistivity up to 
$300 \mathrm{~s}$ confirms this result. If the results, namely a density of 2.9-3.1 gm/cc and a velocity of $6.8-7.2 \mathrm{~km} / \mathrm{s}$, of the Ujjain-Mahan profile can be validated, then R1 and R2 may represent high-density mafic granulites devoid of any fluids.

In the absence of detailed gravity and seismic modeling studies along this profile, the MT model presented here can be explained taking clues from other MT studies carried out elsewhere. Both R1 and R2 can be explained by igneous intrusive, such as granitic complexes, and the crustal structure can be compared to Ruby Mountain, Nevada (see Wannamaker and Doerner, 2002). Bologna et al. (2005) inferred the high-resistive (1,000-10,000 ohm-m) rocks in the lower crust as silicic dry rocks in the central Brazil region. For the Son Narmada region, the estimated temperatures are about $300^{\circ} \mathrm{C}$ at a depth of $20 \mathrm{~km}$ (see Rai and Thiagarajan, 2006). Free water will evaporate from the rocks at a temperature around $250^{\circ} \mathrm{C}$, implying that the inferred igneous granitic complexes in the lower crust is consistent with the observed high resistivities (R1 and R2) in the study region. At temperatures around $350^{\circ} \mathrm{C}$, felsic material turns ductile (Burgmann and Dresen, 2008). Therefore, in the neighboring zones, earlier interpreted Moho reaching near vertical faults (TNF and SNF) turns out to be listric around $20 \mathrm{~km}$ and for this reason, no conductors extend to Moho below these faults.

In general, the deep crust $(20-40 \mathrm{~km})$ in the northern part of the SNF shows low-resistivity values of $<100 \mathrm{ohm}-\mathrm{m}$. For the Mahan-Ujjain profile, seismic velocity and density in the deep crust from 20 to $40 \mathrm{~km}$ ranges from 6.8 to $7.2 \mathrm{~km} / \mathrm{s}$ and from 2.9 to $3.1 \mathrm{gm} / \mathrm{cc}$, respectively. These values indicate that the lower crust is composed of mafic granulites with only a small fluid content. Based on a high gravity value ( -10 to $-20 \mathrm{mgal}$ ), a 5 - to 20 -ohm-m lowresistive body $(\mathrm{C} 1)$ near station 9 between the depths of 15 and $25 \mathrm{~km}$ is interpreted to be an mafic intrusive formed due to underplating. The presence of mafic intrusives in the Son Narmada region has been inferred in several studies (e.g., Verma and Banerjee, 1992). Another important feature is the presence of a low-resistive body (C2) below station 18. C2 is not well resolved and is based on only TE data. However, earlier MT studies also observed similar conducting features in the lower crust in the Son Narmada Region extending north of Narmada River (Gokarn et al., 2001). Hence, C2 is inferred to be a fluid-rich region; this inference is also supported by a low gravity ( -20 to $-40 \mathrm{mgal}$; Fig. 1(b)). The porosity values for the observed conductivity anomalies in the deep crust are calculated using the Hashin and Shtrikman (1963) approximation. For about 20-ohm-m conductors ( $\mathrm{C} 1$ and $\mathrm{C} 2$ ), a porosity value of $7-8 \%$ is required, whereas for the $100-$ ohm-m conducting lower crust, a porosity value of $2 \%$ is required for a brine resistivity of $0.01 \mathrm{ohm}-\mathrm{m}$.

An interpretation of the resistivity model is presented in Fig. 5(b) where a domal structure develops through the underplating of sediments which 'jack-up' the units above. The presented model is consistent with tectonic extrusion and the subsequent exposure through extensive erosion. The mafic and felsic layers are markedly thicker in the domed-up portion in Fig. 5(b). A thicker mafic crust can be explained by younger mafic intrusions related to the Deccan volcanic activity. More geophysical and geological data are needed to better constrain the model for this region.

Acknowledgments. I thank Prof. Makoto Uyeshima for his editorial comments and Dr. Tada-nori Goto and Prof. A. Adam for excellent and helpful reviews which improved the quality of the manuscript. Prof. M. Santosh is thanked for his helpful discussions on the geological model presented in this paper. I thank Prof. Alan Jones for providing the multi-site, multi-frequency MT tensor decomposition code, Dr. R. K. Chadha for all his encouragement, and Dr. V. P. Dimri, the Director, NGRI, for his permission to publish this work.

\section{References}

Almeida, E., F. M. Santos, A. Mateus, W. Heise, and J. Pous, Magnetotelluric measurements in SW Iberia: New data for the Variscan crustal structures, Geophys. Res. Lett., 32, L08312, doi:10. 1029/2005GL022596, 2005.

Bologna, M. S., A. L. Padilha, and I. Vitorello, Geoelectric crustal structures off the SW border of the Sao Francisco craton, central Brazil, as inferred from a magnetotelluric survey, Geophys. J. Int., 162, 357-370, 2005.

Brasse, H., P. Lezaeta, V. Rath, K. Schwalenberg, W. Soyer, and V. Haak, The Bolivian Altiplano conductivity anomaly, J. Geophys. Res., 107(B5), 2096, doi:10.1029/2001JB000391, 2002.

Burgmann, R. and G. Dresen, Rheology of the lower crust and upper mantle: evidence from rock mechanics, geodesy and field observations, Ann. Rev. Earth Planet. Sci., 36, 531-567, 2008.

Ellinghaus, A., PROCMT User's guide, Offline processing software for magnetotelluric time series, v. 2.1, 1-100, 1997.

Gokarn, S. G., C. K. Rao, G. Gupta, B. P. Singh, and M. Yamashita, Deep crustal structure in central India using magnetotelluric studies, Geophys. J. Int., 144, 685-694, 2001.

Hashin, Z. and S. Shtrikman, A variational approach to the theory of the elastic behaviour of multiphase materials, J. Mech. Phy. Solids, 11, 12140, 1963.

Jones, A. G., Electrical properties of the lower continental crust, in Continental Lower Crust, edited by D. M. Fountain, R. Arculus, and R. W. Kay, pp. 81-144, Elsevier Pub., 1992.

Kaila, K. L., P. R. Reddy, M. M. Dixit, and P. K. Rao, Crustal structure across the Narmada-Son lineament, Central India from deep seismic soundings, J. Geol. Soc. India, 26, 465-480, 1985.

Kaila, K. L., P. R. K. Murthy, and D. M. Mall, The evolution of the Vindhyan basin vis-à-vis the Narmada-Son lineament, central India, from deep seismic soundings, Tectonophysics, 162, 271-289, 1989.

Ledo, J., A. G. Jones, I. J. Ferguson, and L. Wolynec, Lithospheric structure of the Yukon, northern Canadian Cordillera, obtained from magnetotelluric data, J. Geophys. Res., 109, B04410, doi:10. 1029/2003jb002516, 2004.

McNeice, G. M. and A. G. Jones, Multi-site, multi-frequency tensor decomposition of magnetotelluric data, Geophysics, 66, 158-173, 2001.

Patro, B. P. K., T. Harinarayana, R. S. Sastry, Madhusudan Rao, C. Manoj, K. Naganjaneyulu, and S. V. S. Sarma, Electrical imaging of NarmadaSon Lineament Zone, Central India from magnetotellurics, Phys. Earth Planet. Inter, 148, 215-232, 2005.

Rai, S. N. and S. Thiagarajan, A tentative 2D thermal model of central India across the Narmada-Son Lineament (NSL), J. Asian Earth Sci., 28, 363-371, 2006.

Ravi Shankar, Heat flow map of India and discussions on its geological and economic significance, Ind. Miner., 42, 89-110, 1988.

Rodi, W. and R. L. Mackie, Nonlinear conjugate gradients algorithm for 2-D magnetotelluric inversion, Geophysics, 66, 174-187, 2001.

Singh, A. P. and R. Meissner, Crustal configuration of the Narmada-Tapti region (India) from gravity studies, J. Geodyn., 20, 111-127, 1995.

Tewari, H. C. and P. Kumar, Deep Seismic Sounding Studies in India and its Tectonc Implications, J. Virtual Explor., 12, 30-54, 2003.

Verma, R. K. and P. Banerjee, Nature of continental crust along the Narmada-Son-Lineament inferred from gravity and deep seismic sounding data, Tectonophysics, 202, 375-397, 1992.

Wannamaker, P. E. and W. M. Doerner, Crustal structure of the Ruby Mountains and southern Carlin Trend region, Nevada, from magnetotelluric data, Ore Geol. Rev., 21, 185-210, 2002.

K. Naganjaneyulu (e-mail: kasturi_kasturi@rediffmail.com) 